\title{
Ratlarda Sisplatin Kaynaklı Nefrotoksisite Üzerine Naringeninin Koruyucu Etkisinin İncelenmesi
}

\author{
İsmail KOYUNCU \\ Harran Üniversitesi, Tıp Fakültesi, Tıbbi Biyokimya Anabilim Dalı, Şanlıurfa, Türkiye.
}

Geliş Tarihi: 01.05.2018

Kabul Tarihi: 07.06.2018

\begin{abstract}
Özet: Naringenin, insan sağlığı üzerinde biyoaktif bir etkiye sahip olup, greyfurtta baskın bulunan doğal bir flavonondur. Bu çalışmada ratlarda sisplatin ile oluşturulan nefrotoksisite üzerine naringenin'in böbrek dokusundaki bazı biyokimyasal parametreler üzerine etkileri araştırıldı. Bu çalışmada, 35 adet 2 aylık wistar albino ratlar kullanıldı. Ratlar rastgele her grupta 7 rat olacak şekilde 5 gruba ayrıldı. 1.grup (Kontrol) \%1'lik DMSO i.p, 2.grup (Cis), tek doz sisplatin., 7 mg/kg / i.p, 3.grup $\left(N G_{20}\right)$ naringenin, $20 \mathrm{mg} / \mathrm{kg} / 10$ gün /i.p, 4.grup, $\left(C i s+N G_{20}\right)$ tekdoz sisplatin $7 \mathrm{mg} / \mathrm{kg} / \mathrm{i} . p+20 \mathrm{mg} / \mathrm{kg} / 10$ gün./i.p naringenin, 5. grup $\left(\mathrm{Cis}+\mathrm{NG}_{40}\right)$ tek doz sisplatin $7 \mathrm{mg} / \mathrm{kg} / \mathrm{i} . \mathrm{p}+40 \mathrm{mg} / \mathrm{kg} / 10$ gün./i.p naringenin on gün boyunca uygulandı. Çalışma sonunda ratlardan alınan böbrek dokusundan biyokimyasal analizler yapıldı. Sisplatin grubunda böbrek TOS, OSI, MDA, AOPP, 8-OHdG ve NRF-2 düzeyleri kontrol grubuna göre artarken $(P<0.05)$, böbrek TAS ve GSH $(P<0.05)$ düzeyleri anlamlı olarak azaldı. Sisplatinin ratlarda oluşturduğu nefrotoksisiteyi, naringenin'in anlamlı olarak azalttı̆̆ından dolayı, sisplatin'e bağı nefrotoksisitenin naringenin ile kontrol edilebileceği sonucuna varılmıştır.
\end{abstract}

Anahtar Kelimeler: Naringenin, DNA hasarı, NRF-2, TAS, TOS.

\section{Investigation of the Protective Effect of Naringenin on the Cisplatin-Induced Nephrotoxicity in Rats}

Abstract: Naringenin which have a bioactive effect on human health is a natural flavonone predominantly found in grapefruit. In this study, the effects of naringenin on some biochemical parameters in renal tissue in cisplatin-induced nephrotoxicity case were investigated in rats. In this study 35 Wistar albino rats, aged 2 months were used. Rats were randomly divided into 5 groups each consisted of 7 rats,; 1.group (control) $1 \%$ DMSO i.p, 2.group (Cis), one dose cisplatin., $7 \mathrm{mg} / \mathrm{kg} /$ i.p, 3.group (NG20) naringenin, $20 \mathrm{mg} / \mathrm{kg} /$ day /i.p, 4.group, (Cis $+\mathrm{NG}_{20}$ ) one dose cisplatin $7 \mathrm{mg} / \mathrm{kg} / \mathrm{i} . \mathrm{p}+20$ $\mathrm{mg} / \mathrm{kg} /$ day./i.p naringenin, 5.group $\left(\mathrm{Cis}+\mathrm{NG}_{40}\right.$ ) one dose cisplatin $7 \mathrm{mg} / \mathrm{kg} /$ i.p $+40 \mathrm{mg} / \mathrm{kg} / \mathrm{day} . / \mathrm{i} . \mathrm{p}$ naringenin were administered for ten days. At the end of the study biochemical analyses were made on samples of kidney tissues. Kidney tissue levels of TOS, OSI, MDA, AOPP, $8-O H d G$ ve NRF-2 were increased $(P<0.05)$ and TAS and GSH levels $(P<0.05)$ were decreased significantly in cisplatin group (2. group) compared with control group. As naringenin significantly reduced nephrotoxicity in cisplatin-induced rats and nephrotoxicity could be controlled with naringenin.

Keywords: Naringenin, DNA damage, NRF-2, TAS, TOS.

\section{Giriş}

Sisplatin, katı tümörlerin pekçok çeşidinde kullanılabilen, etkin bir kemoterapik ajan olmasına karşın, başta nefrotoksisite olmak üzere hepatotoksisite gibi doz bağımlı belirgin yan etkileri klinik kullanımını kısıtlamaktadır (Wang ve ark., 2017). Sisplatin ile yapılan in vivo ve in vitro çalışmalarla bu ajanın serbest radikalleri artırarak, lipit, protein ve DNA hasarına neden olduğu ve oksidatif hasara karşı dokuları koruyan antioksidan enzimlerin aktivitesinin azalmasına neden olduğu tespit edilmiştir. Bu yüzden sisplatinin neden olduğu çeşitli toksisitenin, serbest radikaller veya reaktif oksijen türleri ile ilgili olduğunu göstermektedir (Coşkun ve ark., 2013; Topcu ve ark., 2016).

Günümüzde kanser tedavisinde sisplatinin vazgeçilmez etkin bir kemoterapik ajan olmasından dolayı, daha etkin ve daha az toksik olan sisplatin analoglarının üretilmesi ve sisplatin kullanımıyla beraber antioksidan maddeler kullanılarak sisplatinin neden olduğu yan etkilerin azaltılması için çeşitli çalışmalar yapılmaktadır. Bu amaçla değişik antioksidan ve anti-enflamatuvar maddelerin sisplatin toksisitesine karşı koruyucu etkileri incelenmiştir. Yapılan araştırmalarda ısırgan otu, L-Karnitin ve naringenin-oximegibi antioksidanların koruyucu etki gösterdiği tespit edilmiştir (Özkol ve ark., 2012; Coşkun ve ark., 2013; Koyuncu ve ark., 2017)

Naringenin; greyfurt kabuğundan izole edilen bir fenolik bileşik olup (Kawaii ve ark., 1999), yapılan birçok in-vitro çalışma sonucunda etkili bir antioksidan olduğu, yapılan in-vivo çalışmalarda ise lipit peroksidasyon oluşumunu azalttığı, antioksidan enzim aktivitesini artırdığı tespit edilmiştir (Arul ve 
ark., 2013; Raza ve ark., 2013). Bu çalışma naringenin'in; sisplatinin böbrek dokusunda serbest radikal artışı göstergesi olan TOS, NRF-2 gibi oksidan parametreler ve DNA hasarı üzerindeki etkileri incelenerek böbrek hasar üzerine olası koruyucu etkilerini değerlendirmeyi amaçladık.

\section{Materyal ve Metot}

1. Deney hayvanları ve Deneysel illaç Uygulamaları: Çalışma için kullanılan ratlar DOLLVET Araştırma Merkezi tarafından sağlanmış olup 2014/66 sayılı yazı ile gereken etik kurul belgesi ile onaylanmıştır. Çalışma 35 adet Wistar albino ratlar (8 haftalık yaşta, 200-250 g ağırlığında) ile yapıldı. Ratlar standart laboratuar koşullarında (12 saat ışık, 12 saat karanlık ve $25+3{ }^{\circ} \mathrm{C}$ ) tutularak standart ticari pelet yem ile beslendi. Yem ve su ad libitum verildi. Çalışmada; 1.grup (kontrol) \%1'lik DMSO i.p, 2.grup (Cis), tekdoz sisplatin., $7 \mathrm{mg} / \mathrm{kg} / \mathrm{i} . \mathrm{p}, 3 . \operatorname{grup}\left(\mathrm{NG}_{20}\right)$ naringenin, $20 \mathrm{mg} / \mathrm{kg} / 10$ gün/i.p, 4.grup, $\left(\mathrm{Cis}+\mathrm{NG}_{20}\right)$ tekdoz sisplatin $7 \mathrm{mg} / \mathrm{kg} / \mathrm{i} . \mathrm{p}+20 \mathrm{mg} / \mathrm{kg} / 10$ gün./i.p naringenin, 5.grup (Cis $+\mathrm{NG}_{40}$ ) tek doz sisplatin 7 $\mathrm{mg} / \mathrm{kg} /$ i.p $+40 \mathrm{mg} / \mathrm{kg} / 10$ gün./i.p naringenin on gün boyunca uygulandı.

\section{Böbrek dokularının alınması ve} homojenatlarının hazırlanması: Çalışma sonucunda ratlardan alınan böbrek ve kan dokusunda biyokimyasal analizler yapıldı. Alınan kan tüplere aktarılarak, $3000 \mathrm{rpm}$ 'de, $+4{ }^{\circ} \mathrm{C}^{\prime} \mathrm{de} 10 \mathrm{dk}$ santrifüj edilerek serumları ayrıldı. Böbrek dokuları soğuk PBS tampon ile yıkandıktan sonra, analiz yapılıncaya kadar $-80^{\circ} \mathrm{C}^{\prime}$ de tutuldu. Ratlardan alınan böbrek dokuları $1 / 10$ oranında $\mathrm{pH} 7.4,0.1 \mathrm{M}$, fosfat tamponu ile buz içerisinde homojenize edilerek $1800 \times x^{\prime}$ de santrifüj edildi. Elde edilen sonra süpernatantlar analizler için kullanıldı.

\section{Biyokimyasal Analizler: Lipid} peroksidasyonunun son ürünü olan malondialdehit (MDA) düzeyi serum örneklerinde Ohkawa ve ark. (Ohkawa ve ark., 1979) geliştirdikleri metot kısmen modifiye edilerek yapıldı. Bu yöntemin prensibi MDA'nın TBA ile reaksiyona girerek $535 \mathrm{~nm}$ eksitasyon ve 550 emisyon $\mathrm{nm}^{\prime}$ lerinde maksimum absorbans veren renkli bir kompleks oluşturması esasına dayanır. İleri Oksidasyon Protein Ürünleri (AOPP) düzeyleri, Witko-Sarsat ve ark.'nın (Witko ve ark., 1992) tanımladığı spektrofotometrik yöntemle incelendi. Elde edilen homojenat üzerine $200 \mu \mathrm{K} \mathrm{KI}$ eklendi ve 2 dakika karanlıkta oda Isısında bekletildikten sonra üzerine asetik asit eklenerek örnekler iyice karıştırılıp, oluşan reaksiyon $340 \mathrm{~nm}$ dalga boyunda spektrofotometrik olarak ölçüldü. GSH analizi Ozkol ve ark.'ın (Ozkol ve ark., 2015) yöntemine göre yapıldı. Total oksidan kapasite (TAS) ölçümü ticari kit (Rel Assay, Gaziantep /Türkiye) kullanılarak ölçüldü. Total antioksidan kapasite (TAS) ölçümü ticari kit (Rel Assay, Gaziantep /Türkiye) ile yapıldı. Total oksidan seviye (TOS) / Total antioksidan seviye (TAS) şeklinde bölünerek oksidatif stres indeksi (OSi) hesaplanarak, AU (Arbitrary Unit) olarak ifade edildi. 8-hidroksi-2-deoksiguanozin (8-OHdG)'nin kantifikasyonu OxiSelect Oxidative DNA Damage ELISA Kiti (Cell Biolabs, San Diego, CA) kullanılarak yapıldı. NRF2 'nin kantifikasyonu ELISA Kit (Cusabio, San Diego, CA) protokolü uygulanarak analiz yapıldı. Kan üre (BUN) ve kreatinin (CRE) seviyesi biyokimya otoanalizörü (Beckman Coulter AU680 analyzer) ile yapıldı.

4. İstatistiksel Analizler: Veriler ortalama değerler $(X \pm S D)$ olarak verildi. Grup arasındaki karşılaştırmalar tek yönlü varyans analizini takiben Dunnet testiyle değerlendirildi. Sonuçların önem dereceleri $\mathrm{P}<0,05$. ise anlamlı olarak ifade edildi.

\section{Bulgular}

1. Naringeninin böbrek MDA ve AOPP düzeyleri üzerindeki etkisi: MDA; serbest radikaller tarafından indüklenen lipit hasarını, AOPP ise protein oksidasyonu ölçmek için yaygın olarak kullanılan parametrelerdir. Naringenin ve sisplatinin böbrek dokusu MDA ve AOPP üzerindeki etkileri Şekil 1'de verilmiştir.

Kontrol grubu ile karşılaştırıldığında, sisplatin uygulanan grubun böbrek dokusunda MDA ve AOPP düzeylerinde istatistiksel olarak anlamlı $(P<0.05)$ artış tespit edilirken. Sisplatin ile birlikte naringenin uygulanan gruplarda ise sisplatin grubuna kıyasla MDA ve AOPP düzeylerinde anlamlı $(P<0.05)$ bir azalma olduğu gözlenmiştir (Şekil-1).

2. Naringeninin böbrek GSH düzeyleri üzerindeki etkisi: Glutatyon (GSH), antioksidan enzimlerin serbest radikalleri nötralize etmede kullandığı önemli bir tripeptid antioksidandır. Böbrek GSH düzeyi sisplatin grubunda, kontrol gurubuna göre anlamlı bir şekilde azalırken ( $P$ $<0.05)$, naringenin verilen gruplarda doz artışına bağlı olarak anlamlı bir artış olduğu gözlendi (Şekil 2). 

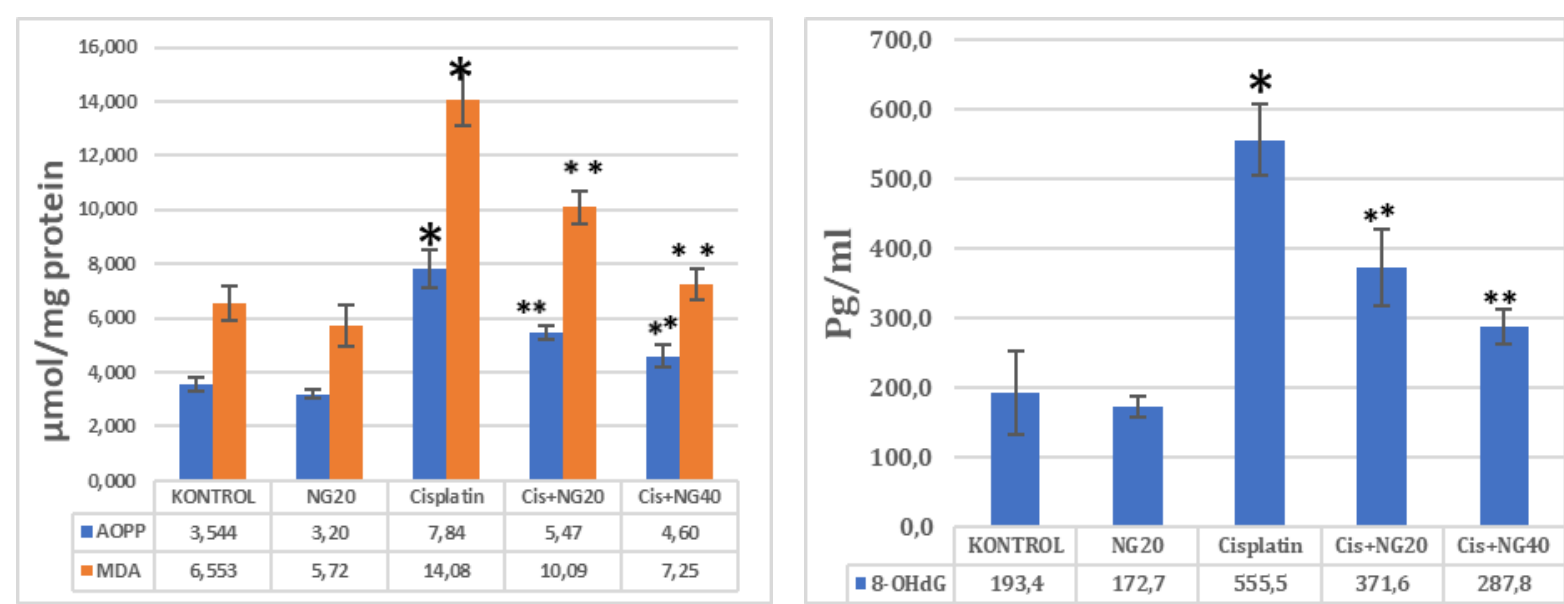

Şekil 1. Sisplatin $(7 \mathrm{mg} / \mathrm{kg})$, naringenin $\left(\mathrm{NG}_{20}\right)$ ve kombinasyonlarının (Cis $+\mathrm{NG}_{20}$ ve $\mathrm{Cis}+\mathrm{NG}_{40}$ ) rat böbrek dokusundaki AOPP, MDA ve 8-OHdGseviyesi üzerindeki etkileri. Değerler ortalama \pm SD $(n=7)$ olarak verilmiştir. ${ }^{*} p<0.05$; Kontrol grubu ile karşılaştırıldığında, ${ }^{* *} \mathrm{p}<0.05$; Cis grubu ile karşılaştıııldığında gruplar arasındaki farklılık istatiksel olarak anlamlı kabul edildi.
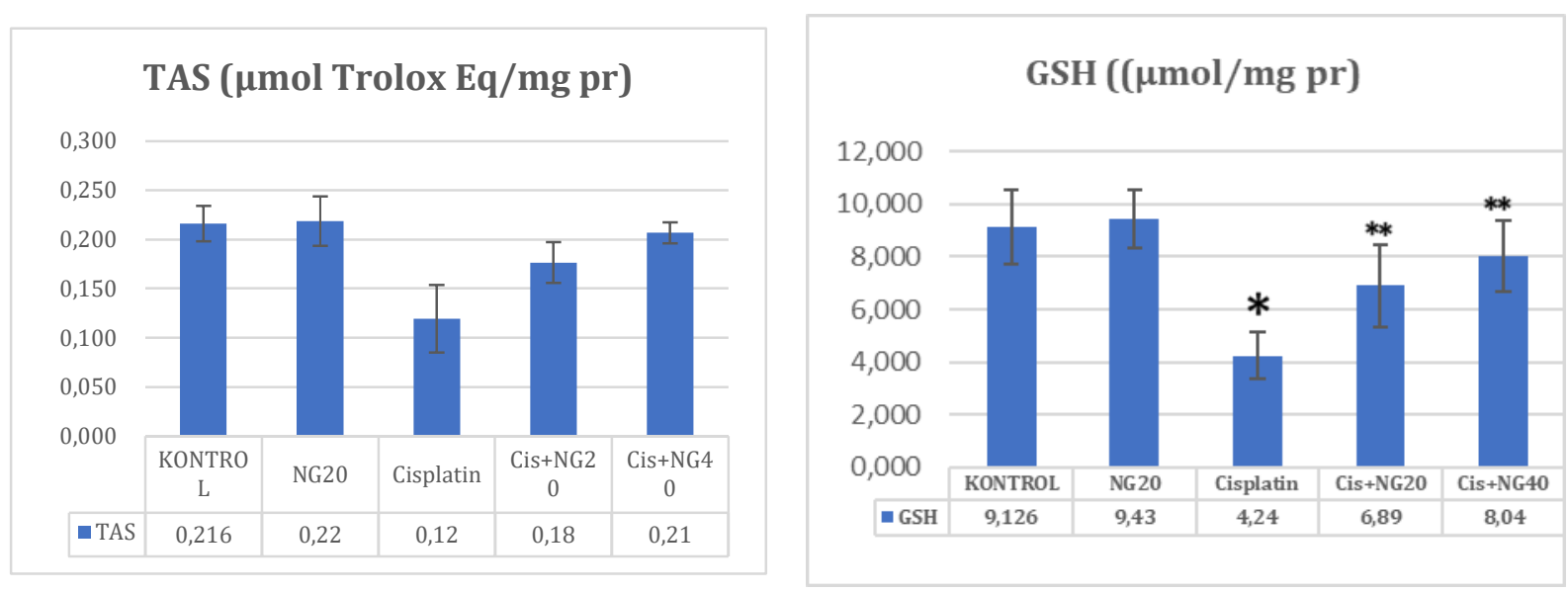

Şekil 2. Sisplatin $(7 \mathrm{mg} / \mathrm{kg})$, naringenin $\left(\mathrm{NG}_{20}\right)$ ve kombinasyonlarının (Cis $+\mathrm{NG}_{20}$ ve $\mathrm{Cis}+\mathrm{NG}_{40}$ ) rat böbrek dokusundaki TAS ve GSH seviyesi üzerindeki etkileri. Değerler ortalama $\pm S D(n=7)$ olarak verilmiştir. ${ }^{*} p<0.05$; kontrol grubu ile karşılaştırıldığında, ${ }^{* *} p<0.05$; Cis grubu ile karşılaştırıldığında gruplar arasındaki farklılık istatiksel olarak anlamlı kabul edildi.

3. Böbrek ve Serum NRF-2 Düzeyleri: Nükleer solunumsal faktör 2 (Nrf2), NQO1 ve diğer detoksifiye edici genler için bir transkripsiyon faktörü olup antioksidan sistemi indüksiyonunu düzenleyen bir transkripsiyon faktörüdür. Oksidatif stres, Nrf2 ekspresyon seviyesinin artması ve fosforilasyonuna neden olur. (Kilic ve ark., 2015). Bu nedenle oksidatif stresin önemli bir belirteci olarak kabul edilmektedir. Çalışmada sisplatin grubu, kontrol gurubuyla karşılaştırıldığında Nrf2 seviyesinin önemli derecede $(P<0.05)$ artarken, naringenin verilen guruplarda anlamlı $(P<0.05)$ bir azalma olduğu gözlendi (Şekil 3 ).
4. Böbrek TAS, TOS ve OSI Düzeyleri: Böbrek dokusundaki total antioksidan (TAS), total oksidan (TOS) ve oksidatif stres indeksi (OSI) sonuçları Şekil 2 ve $3^{\prime}$ de verildi. Kontrol grubu ile Sisplatin gurubu karşılaştırıldığında böbrek dokusunda TAS seviyesinin anlanmlı bir şekilde azaldığı $(p<0.05)$ gözlenirken, sisplatinle beraber naringenin verilen guruplarda TAS seviyesinin arttığı $(p<0.05)$ tespit edildi (Şekil 2 ). TOS ve OSI $(p<0.05)$ düzeylerinin yalnızca sisplatin uygulanan grupta arttı̆̆ı; sisplatinle birlikte naringenin verilen guruplarda ise böbrek TOS ve OSI düzeylerinin sisplatin grubuna göre azaldığı $(p<0.05)$ tespit edildi (Şekil 3). 


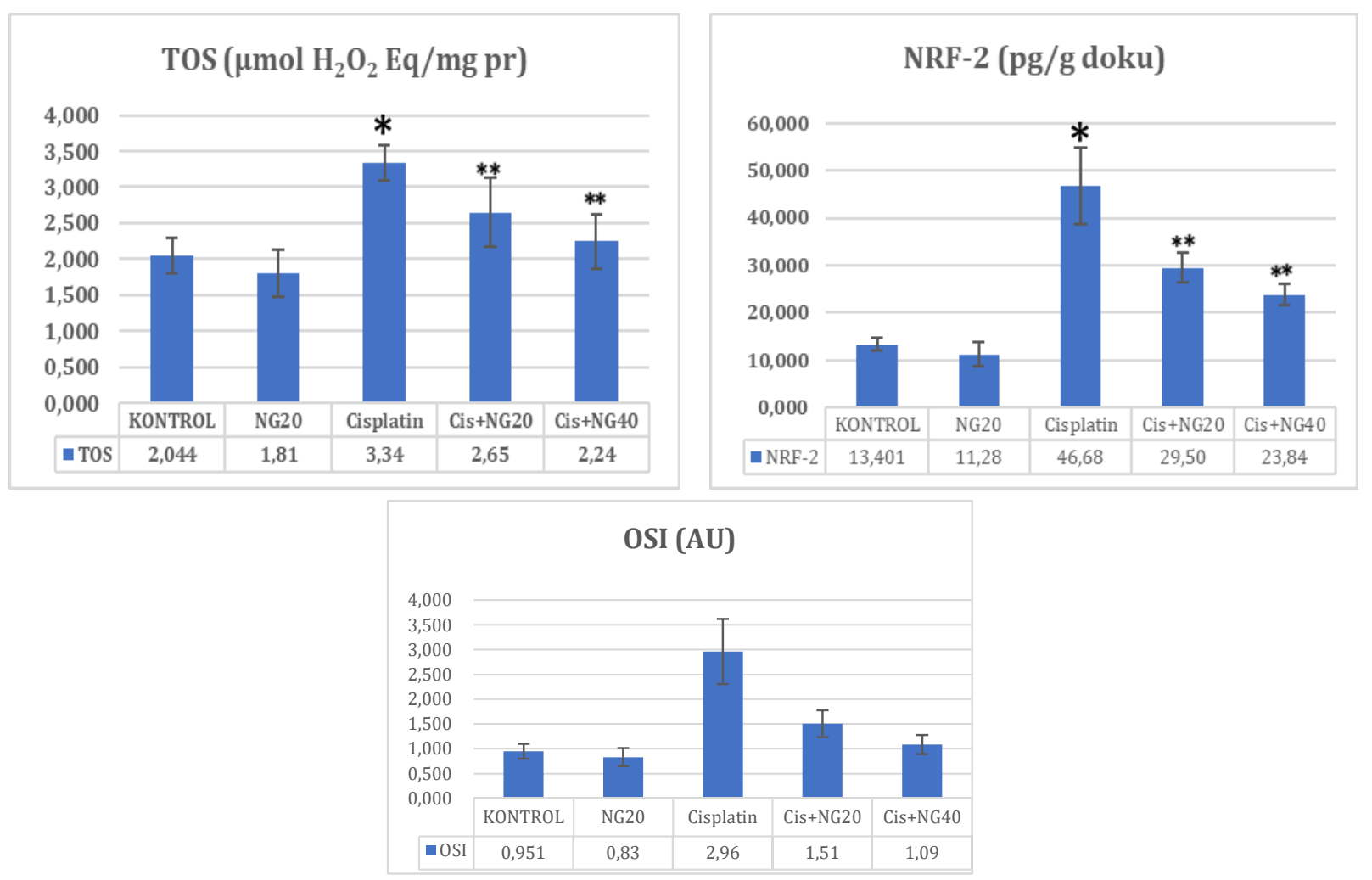

Şekil 3. Sisplatin $(7 \mathrm{mg} / \mathrm{kg})$, naringenin $\left(\mathrm{NG}_{20}\right)$ ve kombinasyonlarının (Cis $+\mathrm{NG}_{20}$ ve $\mathrm{Cis}+\mathrm{NG}_{40}$ ) rat böbrek dokusundaki TOS, OSI ve NRF-2 seviyesi üzerindeki etkileri. Değerler ortalama \pm SD $(n=7)$ olarak verilmiştir. ${ }^{*} p<0.05$; kontrol grubu ile karşılaştırıldığında, **p<0.05; Cis grubu ile karşılaştırıldığında gruplar arasındaki farklılık istatiksel olarak anlamlı kabul edildi.
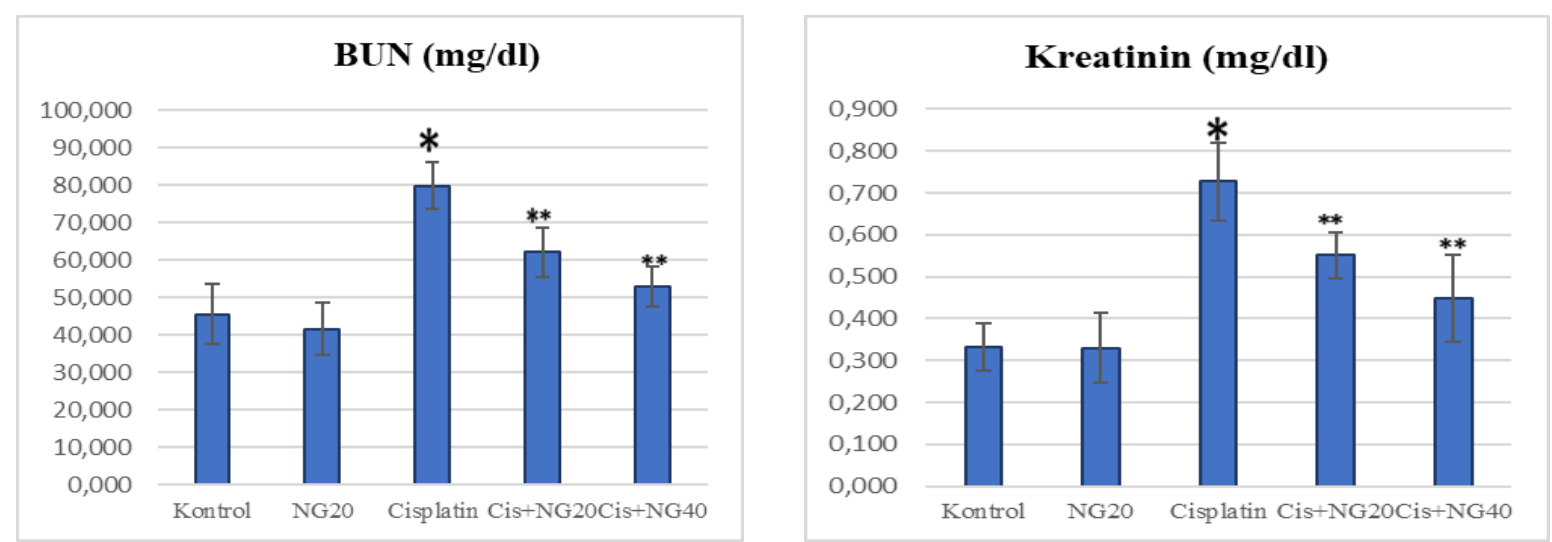

Şekil 4. Sisplatin $\left(7 \mathrm{mg} / \mathrm{kg}\right.$ ), naringenin $\left(\mathrm{NG}_{20}\right)$ ve kombinasyonlarının (Cis $+\mathrm{NG}_{20}$ ve $\mathrm{Cis}+\mathrm{NG}_{40}$ ) rat serum dokusundaki BUN ve kreatinin seviyesi üzerindeki etkileri. Değerler ortalama $\pm S D(n=7)$ olarak verilmiştir. ${ }^{*} p<0.05$; Kontrol grubu ile karşılaştırıldığında, ${ }^{* *} p<0.05$; Cis grubu ile karşılaştırıldığında gruplar arasındaki farklılık istatiksel olarak anlamlı kabul edildi.

5. Böbrek 8-OHdG Düzeyleri: 8-Hidroksi deoksiguanozin (8-OHdG), oksidan kaynaklı DNA hasarının önemli işaretlerinden biridir. Tüm grupların 8-OHdG düzeylerindeki değişimler Şekil 1'de gösterilmiştir. Sisplatin grubunda $8-\mathbf{O H d G}$ düzeyleri kontrol grubuna göre önemli derecede artarken $((p<0.05)$, sisplatin uygulamasını takiben naringenin verilen gruplarda 8-OHdG düzeylerinin normale indiği ve kontrol grubuna göre farklılık göstermediği tespit edildi. 
6. Serum Böbrek Fonksiyon test Düzeyleri: Böbrek fonksiyon testleri BUN ve kreatinin seviyeleri serumda analiz edilerek sonuçlar Şekil 4 verildi. Sisplatin verilen gruplarda kontrol grubuna göre BUN ve kreatinin seviyelerinde önemli artış $(p<0.05)$ gözlenirken, naringenin ile tedavi edilen gruplarda anlamlı bir azalmanın $(p<0.05)$ olduğu tespit edilmiştir.

\section{Tartışma ve Sonuç}

Günümüzde daha etkin ve daha az toksik olan sisplatin analoglarının üretilmesi ve sisplatin kullanımıyla beraber antioksidan maddeler kullanılarak sisplatinin neden olduğu yan etkilerin azaltılması için çeşitli çalışmalar yapılmaktadır. Bu amaçla karboplatin gibi Pt merkezli ve nefrotoksik olmayan türevler geliştirilmiştir. Ancak, sisplatin halen Pt içeren ajanlar arasında en çok tercih edilen hem de en sık kullanılan kemoterapötiklerden biri olmayı sürdürmeye devam ettiğinden, tek alternatif yol olarak sisplatin normal hücreler üzerindeki toksisitesini azaltan ve aynı zamanda kanser hücreleri üzerinde sinerji sağlayan antioksidan maddelerin araştırılması yönünde olmaktadır (Ali ve ark., 2006; Hosseinian ve ark., 2016). Sisplatinin serbest radikal artışına bağlı olarak gelişen yan etkilerini belirlemek amacıyla yapılan çalışmalarda dokularda görülen hasarı indirgeyebilmek için çeşitli kimyasal ajanlar kullanılmaktadır. Sisplatinin istenmeyen yan etkilerinin daha etkili, ekonomik ve kolay uygulanabilir ilaçlarla önleyebilmek ve azaltabilmek amacıyla yapılan bu çalışmalarda en çok kullanılan maddeler antioksidanlardır (Yousef ve ark., 2009). Bu çalışma sisplatinin neden olduğu nefrotoksisite ve böbrek DNA hasarı üzerine naringenin'in koruyucu etkilerini incelemek amacıyla yapıldı. Çalışma sonucunda sisplatinin böbrek dokusunda oksidatif stres artışına, antioksidan sistemin azalmasına bağlı DNA hasarına yol açarak nefrotoksite'ye yol açtığı tespit edildi. Naringenin'in ise antioksidan sistemi tetikleyerek ve serbest radikalleri nötralize ederek böbrek hasarını azalttığı gözlendi.

Oksidatif stres, serbest radikallerin oluşumu ve ortadan kaldırılması arasındaki dengenin bozulması sonucunda oluşmaktadır. Özellikle sisplatin gibi çeşitli kemoterapik maddeler vücutta aşırı oksidan üretimine veya antioksidan mekanizmanın zayıflamasına yol açarak oksidatif stresin artışına yol açmaktadır (Yousef ve ark., 2009). Oksidatif stresin değerlendirilmesinde birçok molekül ve yöntem geliştirilmiştir. Ancak çeşitli çalışmalar TAS ve TOS parametrelerinin oksidatif stres ile ilişkili hastalıklar için yararlı belirteçler olabileceğini bildirmektedir.
$\mathrm{Bu}$ nedenle son yıllarda örnekteki net oksidan ve antioksidan durumu ve bunların dengesini belirlemek için TOS, TAS ölçülmekte ve OSI'nin hesaplanması önerilmektedir (Erel, 2005; Xiao ve ark., 2018). Bu nedenle OSi; sisplatin aracılı genotoksisite, hepatotoksisite ve nefrotoksisi için gerekli bir gösterge olarak kabul edilebilir. Sisplatin verilen grupta kontrol grubuna göre TOS ve OSI seviyesi önemli derecede artış gösterirken, TAS seviyesinde önemli bir azalma gözlenmiştir. Bunun aksine naringenin ile tedavi edilen grupta TAS seviyesinin artışına bağlı olarak TOS ve OSI seviyesi önemli derecede azaldı. Bu sonuçlar sisplatine maruz kalmanın dokularda oksidatif streste bir artışa neden olduğunu ve oksidatif stresin naringenin tedavisi ile engellendiğini göstermektedir.

Birçok hücre tipinde, oksidatif strese karşı çok sayıda hücresel yanıtın, antioksidan tepki elemanı (ARE) ve transkripsiyon faktörü, nükleer faktör eritroid 2-ilişkili faktör-2 (Nrf2) aracılığıyla hareket eden sinyal oluşturucu proteinlere dahil olduğu bulunmuştur (Sies ve ark., 1996). Nrf2 çeşitli faz 2 detoksifiye ve anti-oksidan enzimlerin ARE aracılı indüksiyonu yoluyla hücreyi oksidatif strese karşı korumaktadır. Nrf2 sinyalleme yolu, geniş bir uyarıcı dizisine yeniden katılan bir dizi antioksidan genin ekspresyonunu yukarı regüle ederek oksidatif strese karşı hücreyi korur (Huang ve ark., 2002; Lee ve ark., 2005). Çalışmamızda sisplatinin Nrf2 seviyesini yükseltirken naringenin uygulamasının Nrf2 ekspresyonunda önemli azalışa yol açmıştır. Bu çalışmanın sonuçları Nrf2 antioksidatif stres sinyallemesi ile naringenin nefroprotektif etkisi arasında olası bir ilişki olduğunu göstermektedir. Hücre içi artan serbest radikaller DNA 'da önemli hasarlara yol açabilir. 8-OHdG ise oluşan, DNA hasarının en önemli göstergesi olarak kabul edilmektedir (Cadet ve ark., 2003; Geyikoglu ve ark., 2017). Altuner ve ark., (2013) sıçan yumurtalıklarında tek doz sisplatin uygulaması takiben DNA hasarının arttığını ileri sürmüşlerdir. Elde ettiğimiz sonuçlarda, 8-OHdG seviyesinin, ratlarda sisplatin kaynaklı böbrek DNA hasarının iyi bir göstergesi olduğunu gösterdi. Daha önce yapılan çalışmalarda, DNA hasarının antioksidan desteği ile azaldığı tespit edilmiştir (Ince ve ark., 2014). Çalışmamızda elde edilen sonuçlarda bu verileri desteklemiştir. Çalışmada naringeninin sisplatin kaynaklı oksidatif DNA hasar seviyesini antioksidan etki göstererek önemli seviyede azaltarak koruyucu etki göstermiştir.

Malondialdehit, lipid peroksidasyonunun bir göstergesi olarak kullanılan reaktif bir karbon bileşendir (Özkol ve ark., 2012). Önceki çalışmalarla 
uyumlu olarak sisplatin verilen farelerin serum ve böbrek dokusunda MDA düzeylerinde artış gözlenmiştir (Wozniak ve ark., 2004). Bu, patogenezde ROS aracılı akciğer hasarının katılımını kanıtlamaktadır. Naringenin uygulaması, düşük MDA düzeylerinden anlaşılacağı üzere, sisplatin ile indüklenen oksidatif stresini önemli ölçüde azaltmıştır.

GSH, antioksidan sistemin oksijen radikallerini nötralize etmesi için şart olduğundan, hücre içi GSH konsantrasyonu, sisplatin kaynaklı böbrek hasar derecesinin önemli belirleyicisidir (Felgines ve ark., 2000). Sisplatin tarafından üretilen $\mathrm{GSH}$ düzeylerindeki önemli bir düşüş, hücresel redoks durumunda bir değişikliği gösterir, bu da hücrelerin ROS'a daha duyarlı olabileceğini gösterir. Bu, antioksidan enzim savunma mekanizmasının etkinliğinde bir azalmaya neden olur (Soliman ve ark., 2016). Bu çalışmada, Sisplatin ile birlikte naringenin uygulan grupta serum ve böbrek dokularındaki GSH düzeylerindeki artış, oksidatif strese hücresel yanıtta bir artış olduğunu düşündürmektedir. Hem kreatin hem de BUN, sisplatin ile tedavi edilmiş ratlarda anlamlı bir şekilde artmıştır; Bununla birlikte, sisplatinin bu etkileri naringenin tedavisi ile tersine döndü. Bu değişiklikler naringenin tedavisi ile önlenmiştir.

Sonuç olarak, bu çalışma Naringenin flavonoid bileşiğinin ratlarda sisplatinin neden olduğu nefrotoksisitenin ve genotoksisitenin azaltılmasında koruyucu bir role sahip olduğunu göstermektedir.

\section{Kaynaklar}

Ali BH, Al Moundhri M, 2006: Agents ameliorating or augmenting the nephrotoxicity of cisplatin and other platinum compounds: a review of some recent research. Food and Chemical Toxicology, 44, 8, 1173-1183.

Arul D, Subramanian P, 2013: Inhibitory effect of naringenin (citrus flavonone) on Nnitrosodiethylamine induced hepatocarcinogenesis in rats. Biochemical and Biophysical Research Communications, 434, 2, 203-209.

Cadet J, Douki T, Gasparutto D, Ravanat J, 2003: Oxidative damage to DNA: formation, measurement and biochemical features. Mutation Research/Fundamental and Molecular Mechanisms of Mutagenesis, 531, 1, 5-23.

Coşkun NM, Hatipoğlu T, Özoğul C, Korkmaz C, Akyol SN, Mıcılı SC, Arık GS, Erdoğan D, 2013: The protective effects of acetyl L-carnitine on testis gonadotoxicity induced by cisplatin in rats. Balkan Medical Journal, 30, 2, 235.

Erel, O., 2005: A new automated colorimetric method for measuring total oxidant status. Clinical Biochemistry, 38, 12, 1103-1111.
Felgines C, Texier O, Morand C, Manach C, Scalbert A, Régerat F, Remesy C, 2000: Bioavailability of the flavanone naringenin and its glycosides in rats. American Journal of Physiology-Gastrointestinal and Liver Physiology, 279, 6, G1148-G1154.

Geyikoglu F, Emir M, Colak S, Koc K, Turkez H, Bakir M, Hosseinigouzdagani M, Cerig S, Keles ON, Ozek NS, 2017: Effect of oleuropein against chemotherapy drug-induced histological changes, oxidative stress, and DNA damages in rat kidney injury. Journal of Food and Drug Analysis, 25, 2, 447-459.

Hosseinian S, Rad AK, Mousa-Al-Reza Hadjzadeh NM, Roshan SH, Shafiee S, 2016: The protective effect of nigella sativa against cisplatin-induced nephrotoxicity in rats. Avicenna Journal of Phytomedicine, 6, 1, 44.

Huang HC, Nguyen T, Pickett CB, 2002: Phosphorylation of $\mathrm{Nrf2}$ at Ser-40 by protein kinase $\mathrm{C}$ regulates antioxidant response element-mediated transcription. Journal of Biological Chemistry, 277, 45, 42769-42774.

Ince S, Acaroz DA, Neuwirth O, Demirel HH, Denk B, Kucukkurt I, Turkmen R, 2014: Protective effect of polydatin, a natural precursor of resveratrol, against cisplatin-induced toxicity in rats. Food and Chemical Toxicology, 72, 147-153.

Kawaii S, Tomono Y, Katase E, Ogawa K, Yano M, 1999: Quantitation of flavonoid constituents in citrus fruits. Journal of Agricultural and Food Chemistry, 47, 9, 3565-3571.

Kilic U, Sahin K, Tuzcu M, Basak N, Orhan C, Elibol-Can B, Kilic E, Sahin F, Kucuk O, 2015: Enhancement of cisplatin sensitivity in human cervical cancer: epigallocatechin-3-gallate. Frontiers in Nutrition, 1, 28.

Lee JM., Li J, Johnson DA, Stein TD, Kraft AD, Calkins MJ, Jakel RJ, Johnson JA, 2005: Nrf2, a multi-organ protector. The Faseb Journal, 19, 9, 1061-1066.

Ohkawa H, Ohishi N, Yagi K, 1979: Assay for lipid peroxides in animal tissues by thiobarbituric acid reaction. Analytical Biochemistry, 95, 2, 351-358.

Ozkol HU, Koyuncu I, Tuluce Y, Dilsiz N, Soral S, Ozkol H, 2015: Anthocyanin-rich extract from Hibiscus sabdariffa calyx counteracts UVC-caused impairments in rats. Pharmaceutical Biology, 53, 10, 1435-1441.

Ozkol HU, Musa D, Tuluce Y, Koyuncu I, 2012: Ameliorative influence of Urtica dioica $L$ against cisplatin-induced toxicity in mice bearing Ehrlich ascites carcinoma. Drug and Chemical Toxicology, 35, 3, 251-257.

Raza S, Khan M, Ahmad A, Ashafaq M, Islam F, Wagner A, Safhi M, 2013: Neuroprotective effect of naringenin is mediated through suppression of NF-KB signaling pathway in experimental stroke. Neuroscience, 230, 157-171.

Sies H, Masumoto H, 1996: Ebselen as a glutathione peroxidase mimic and as a scavenger of peroxynitrite. Advances in Pharmacology Elsevier. 38: 229-246. 
Soliman AM, Desouky S, Marzouk M, Sayed AA, 2016: Origanum majorana attenuates nephrotoxicity of cisplatin anticancer drug through ameliorating oxidative stress. Nutrients, 8, 5, 264.

Topcu-Tarladacalisir Y, Sapmaz-Metin M, Karaca T, 2016: Curcumin counteracts cisplatin-induced nephrotoxicity by preventing renal tubular cell apoptosis. Renal Failure, 38, 10, 1741-1748.

Wang J, Gu BJ, Masters CL, Wang YJ, 2017: A systemic view of Alzheimer disease - insights from amyloidbeta metabolism beyond the brain. Nat Rev Neurol, $13,10,612-623$.

Witko V, Nguyen AT, Descamps-Latscha B, 1992: Microtiter plate assay for phagocyte-derived Taurine-chloramines. Journal of Clinical Laboratory Analysis, 6, 1, 47-53.

Wozniak, K., A. Czechowska and J. Blasiak, 2004: Cisplatinevoked DNA fragmentation in normal and cancer cells and its modulation by free radical scavengers and the tyrosine kinase inhibitor STI571. Chemicobiological interactions, 147, 3, 309-318.

Xiao Y, Sun H, Li C, Li Y, Peng S, Fan C, Teng W, Shan Z, 2018: Effect of iodine nutrition on pregnancy outcomes in an iodine-sufficient area in China. Biological Trace Element Research, 182, 2, 231-237.

Yousef M, Saad A, El-Shennawy L, 2009: Protective effect of grape seed proanthocyanidin extract against oxidative stress induced by cisplatin in rats. Food and Chemical Toxicology, 47, 6, 1176-1183.

*Yazışma Adresi: İsmail KOYUNCU

Harran Üniversitesi, Tıp Fakültesi, Tıbbi Biyokimya

Anabilim Dalı, Şanlıurfa, Türkiye.

e-mail: ismailkoyuncu1@gmail.com 